\title{
Assessment of Avifaunal Diversity and Threats to them in Phewa Wetland, Nepal
}

\author{
Namrata Devi Khatri ${ }^{*}$, Bijaya Neupane ${ }^{1}$, Yajna Prasad Timilsina ${ }^{1}$ and \\ Suman Ghimire ${ }^{2}$
}

Abstract : We assessed species diversity and relative abundance during February - March by employing transect method in four line transects and 30 point count stations, and associated threats by direct observations and consultation with people $(n=1)$ living in vicinity of Phewa wetland. We counted 2651 bird individuals of 148 species belonging to 104 Genera of 44 Families under 11 Orders. Anatidae and Passeriformes with 11\% and 39\%, respectively were the dominant family and order among the recorded species. Out of these, seven bird species were globally threatened and 12 were nationally threatened. Terrestrial birds had higher species diversity $\left(H^{\prime}=3.27\right)$, species richness $(R=11.98)$ and species evenness $(\mathrm{e}=0.74)$ as compared to wetland birds $\left(\mathrm{H}^{\prime}=3.07, \mathrm{R}=8.44\right.$ and $\mathrm{e}$ $=0.73)$. Common pigeon $(7.50 \%)$ was the most abundant bird followed by lesser whistling duck (6.98\%). People in the vicinity of Phewa wetland reported that water pollution caused by domestic sewages and waste water disposal was the major threat to birds and their habitat. Phewa wetland is providing crucial habitat to adequate residential and migratory bird species for which it should be protected for further enhancement of number of avian species.

Key words: Relative abundance, species diversity, terrestrial bird, wetland bird, globallay and nationally threatened species

Khatri, N.D., Neupane, B., Timilsina, Y.P, Ghimire, S. (2019): Assessment of Avifaunal Diversity and Threats to them in Phewa Wetland, Nepal. Forestry: Journal of Institute of Forestry, Nepal. No. 16: page 31 to 47.

\footnotetext{
${ }^{1}$ Tribhuwan University, Institute of Forestry, Pokhara Campus, Nepal

*Corresponding Author, email: khatrinamrata68@gmail.com

${ }^{2}$ Department of National Park and Wildlife Conservation, Kathmandu
} 


\section{Introduction}

Wetlands, being the transition phase between terrestrial and aquatic habitats, are rich source of biological diversity. They have diverse utilitarian value for different living organisms; however, birds use wetlands basically for breeding, nesting and feeding purposes (Mutagwaba 2010; Parchizadeh, Williams 2018). These wetland birds play vital role in aquatic ecosystem by acting as predators, pollinators and bio-indicators of ecological condition of water bodies (Green, Elmberg 2014).

Among 886 bird species recorded from Nepal (DNPWC, BCN 2018); 40 are globally threatened, 19 are near threatened (IUCN 2018) and 200 are wetland dependent (Baral 2009). The wetlands of Nepal support a total of $40(27 \%)$ of nationally threatened bird species. At present, 10 globally significant wetlands with the total area of 60,561 ha have been declared as Ramsar Sites of international significance as they support large number of residential and migratory birds. Lake cluster of Pokhara Valley, the largest Ramsar site with nine lakes and area of $262 \mathrm{~km}^{2}$ within the Chitwan-Annapurna Landscape, harbors 128 species of vertebrates that include 32 species of mammals (18 Families), 140 birds (37 Families), 24 reptiles, 27 fishes and 11 amphibians (Tamrakar 2008). Phewa, the largest in this cluster and second largest in the country provides home for 104 bird species (43 water birds and 14 migratory species) (MOFE 2018). Gautam and Kafle (2007) in an annual survey from August 2003 to July 2004 recorded a total of 43 species of water birds of 14 families. Furthermore, Giri and Chalise (2008) studied seasonal diversity and population status of water birds from 2007 to 2008, and recorded a total of 39 species belonging to 17 families.

Nepal's wetlands are facing tremendous anthropogenic pressure (IUCN 2004), which includes industrial pollution, intensification of agriculture, land encroachment, deforestation, over-fishing, eutrophication, sedimentation, siltation, soil erosion, pollution and diminution because of which they are degrading rapidly and hazardously (Baral, Inskipp 2005; Giri, Chalise 2008; Acharya, Rajbhandari 2012). All of these disturbances threaten wetland ecosystems, and can greatly influence the population structure and diversity of the bird community supported by that ecosystem (Birdlife International, Corsby 2003). The loss of wetland communities leads to loss of plant diversity, reduction in primary production and consequently loss of faunal diversity of wetland ecosystem due to loss of habitat, food, decreased aeration of sediments and increased nutrient levels (Epaphras et al. 2007; Armstrong et al. 2008). A comparative analysis of the four National Red Data Lists from 1996 to 2010 of the critically endangered (CR) birds and their dependency in the habitat reveals that 28 species listed under this category are wetland dependent species which 
implies 35\% of total wetland bird species in Nepal are considered threatened, far more than other habitat types (Baral et al. 2012).

Phewa wetland is also facing extreme anthropogenic pressure especially siltation and sedimentation. Consequently, the feeding and nesting sites of bird species are gradually modified affecting their survival in this wetland. Therefore, a thorough study is essential to analyze the status of avifaunal diversity in current habitat condition and to update the existing checklist provided by Gautam and Kafle (2007). Hence, we conducted this study with the aim to document species composition and relative abundance of bird fauna, and to identify threats faced by them in Phewa wetland. Additionally, this baseline information on bird diversity will provide starting point to bird scientists to track changes in population of particular bird species.

\section{Materials and Methods}

\section{Study Area}

Phewa, the largest lake of lake- cluster of Pokhara valley and the second largest lake of Nepal, is a semi-natural freshwater lake. It is located at an altitude of 784 $\mathrm{m}$ in Pokhara metropolitan city, Gandaki province of Nepal, and its water surface occupies an area of $4.33 \mathrm{~km}^{2}$ (Figure 1). As per the feasibility study, a total of $5.9 \mathrm{~km}^{2}$ of Phewa wetland area was taken. The lake area provides home to several important species including globally threatened migratory birds, such as critically endangered Baer's pochard (Aythya baeri) and Indian griffon (Gyps indicus) and threatened mammals such as clouded leopard (Neofelis nebulosa), common leopard (Panthera pardusfusca) and Indian pangolin (Manis crassicaudata) (MOFE 2018). The vegetation in the area is a mosaic of sub-tropical and temperate broad-leaved forests, including Sal (Shorea robusta) in the south, riparian forests (Acacia catechu and Dalbergia sisoo) along the banks of Seti river and its tributaries, and Schima-Castanopsis forests in the north and west. Sedimentation due to heavy loads of sediments during and after road construction and debris flow from Harpan and Andheri khola (streams) have resulted in decrease in core water area of Phewa lake at $4 \%$ over the past 20 years (MOFE 2018) whereas forest, grassland, shrub land and urbanization have been increasing (Dixit et al. 2015). The main drivers of degradation include conversion of watershed and lake reservation lands into private land including agricultural land, haphazard building and road construction, reclamation of lake area and encroachment, sedimentation and siltation, pollution and eutrophication, spread of alien invasive species such as water hyacinth (Eichhornia crassipes), overharvesting of fish and illegal poaching (MOFE 2018). 


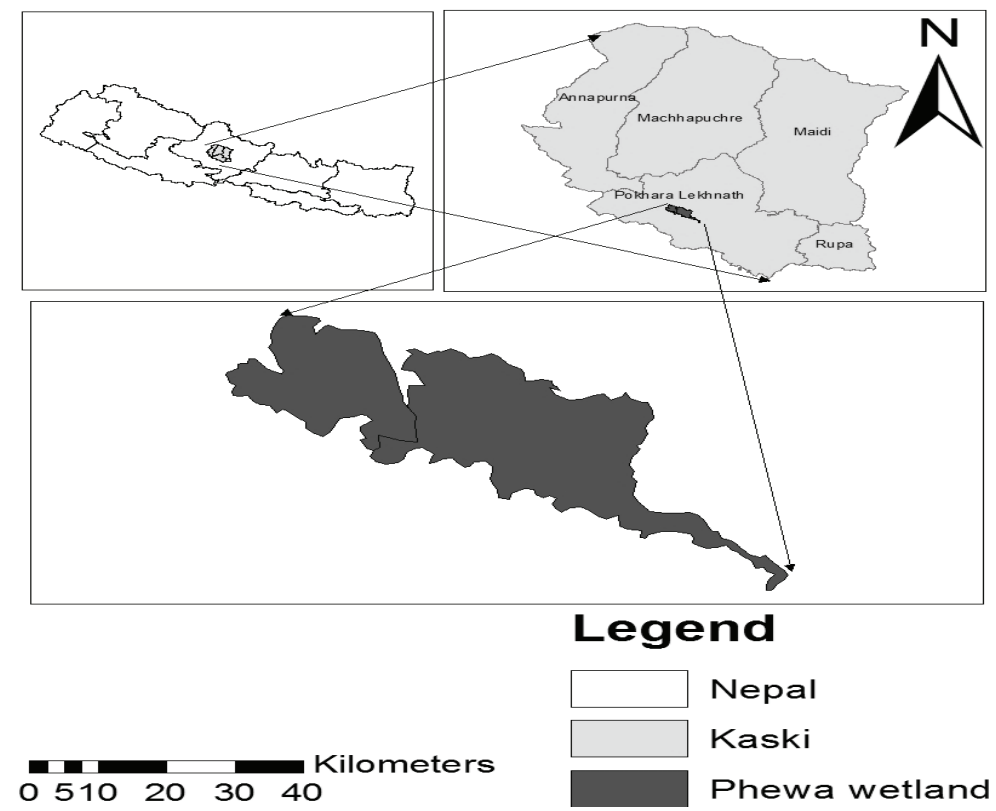

Figure 1 : Location Map of Phewa Wetland

\section{Methods}

\section{Data Collection}

\section{Bird Survey}

By dividing the study area into two strata as water surface and sedimentation area, absolute count of birds was made following Gregory et al. (2004) and Ralph et al. (1995) along four line transects and 30 point count stations in respective strata. Species were recorded along with their numbers during two months between 07.00 and 10.00 AM since peak activities of birds lasts 1- 2 hours after sunrise. The birds were then identified at species level with a popular guide, Helm Field Guide "Birds of Nepal" (Nepali version) (Grimmett et al. 2003) and whenever possible, photographs were taken and calls also recorded to aid in identification process. Field observations were not carried out during adverse environment condition.

\section{Household survey}

Considering households within $1 \mathrm{~km}$ from the edge of lake to be well knowledgeable about status of the lake and birds, altogether 91 respondents comprising farmers, boaters, hoteliers and elites were interviewed with semistructured questionnaire in order to collect information regarding status of bird fauna and their habitat as well as natural and anthropogenic threats to wetland and their habitat. 


\section{Data analysis}

BirdLife International, Crosby (2017) was followed for nomenclature and classification of recorded bird species. IUCN Red List Series (2018) and Inskipp et al. (2016) were followed to assess the global and national conservation status of species. The relative abundance of each observed species was determined in percentage by dividing numbers of individuals of particular recorded species by total number of individuals of recorded species. Following Khan (2005), abundance status of the species was assessed as very common, common, uncommon and rare based on their respective observation rates of $75-100 \%$, $50-74 \%, 25-49 \%$ and $<25 \%$. The species diversity was determined using diversity indices:

Shannon - Wiener Diversity Index (1949): $\mathrm{H}^{\prime}=-\sum \frac{n i}{N}$ in $\frac{n i}{n}$

i. Margalef's Richness Index (Margalef 1958): $\mathrm{R}=\frac{\mathrm{S}-1}{i n N}$ and

ii. Pielou's Evenness Index (Pielou 1966): $\mathrm{E}=\frac{H^{\prime}}{\text { in } S}$

Where, $\mathrm{ni}=$ species abundance, $\mathrm{N}=$ total abundance, $\mathrm{s}=$ total number of species and $\ln =$ logarithm to base e.

Threats identified through direct observation and household survey, were ranked statistically and most promising threat was identified using the weighted mean.

\section{Results and Discussion}

\section{Species Composition}

This study revealed 2651 bird individuals of 148 species belonging to 103 genera and spread over 44 families of 11 orders (Annex 1). Out of the total recorded bird species, $63(57 \%)$ were wetland-dependent birds and $85(43 \%)$ terrestrial birds, which depict that the wetland is highly important habitat supporting diverse birdspecies to perform multiple activities, such as foraging, breeding, loafing and roosting. Some species, such as river lapwing (Vanellus duvaucelii), short eared owl (Asio flammeu) and greater scaup (Greater Scaup) were sighted for the first time in this wetland (Ghimire 2018 pers.comm.). Gautam and Kafle (2007) had recorded a total of 43 species of waterbirds of 14 families from August 2003 to July 2004 and Giri and Chalise (2008) recorded 39 species of water birds of 17 families from 2007 to 2008. This variation in total number of recorded bird species may be due to the season of study as our study was carried out during transition period between winter and summer and with focus on overall composition of avifaunal species. 
Among families, Anatidae emerged as the dominant family (11\%) followed by Accipitridae (8\%), Ardediae (5\%) and so on (Figure 2). Similarly, Passeriformes was the most dominant order with $57(39 \%)$ species of 21 families followed by Falconiformes (Figure 3). In contrast, Giri and Chalise (2008) had recorded Ciconiiformes as the dominant order with 18 species in their one-year survey of water birds while our study recorded only 12 species of order Ciconiiformes. This discrepancy may be the result of habitat modification as recent studies suggest that siltation and sedimentation are gradually reducing effective depth and surface area of Phewa Lake (Heyojoo, Takhachhe 2014; MOFE 2018). Water level is a major factor that directly or indirectly influences waterbird species composition and relative abundance in the wetland (Rajpar and Zakaria 2011).

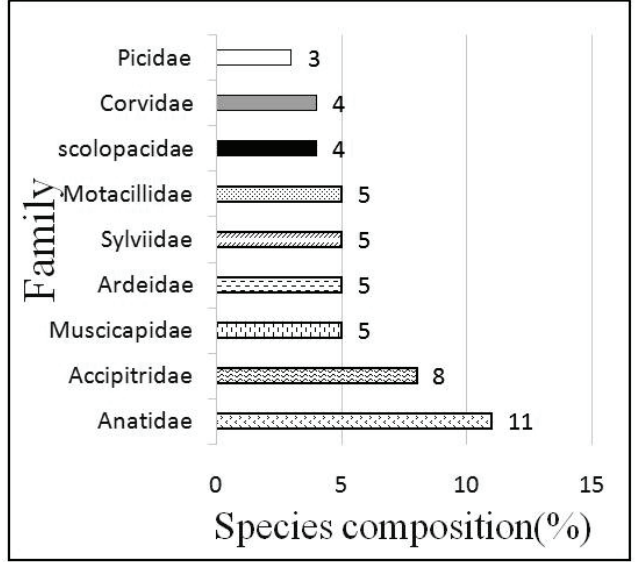

Figure 2 : Species Composition based on Order

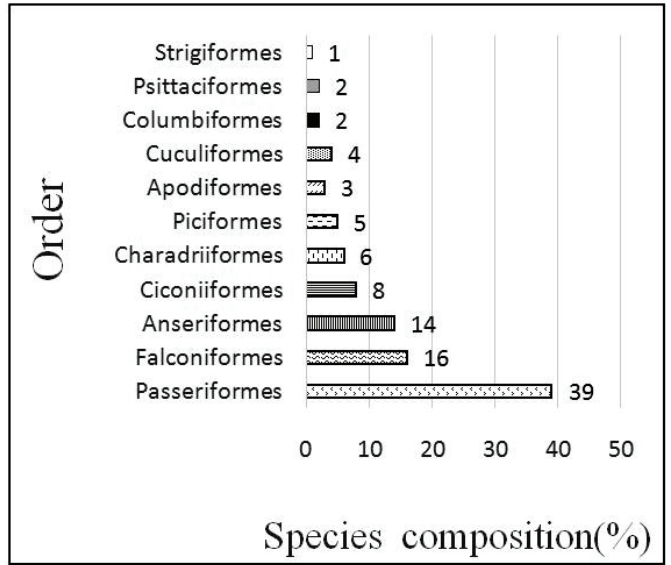

Figure 3 : Species Composition based on Family

Of the total recorded species, 78 were resident followed by winter migrant with 70 species (Figure 4). In addition, the abundance category showed that of 148 bird species, 63 species were Rare, 46 species Uncommon, 18 species Common and 21 species Very common (Figure 5).

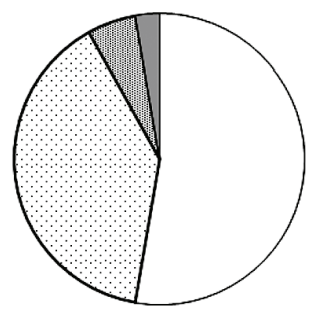

$\square$ Resident $\square$ Winter migrant 圆Passage migrant $\square$ Vargant

Figure 4 : Migratory Status of Avifauna in Phewa

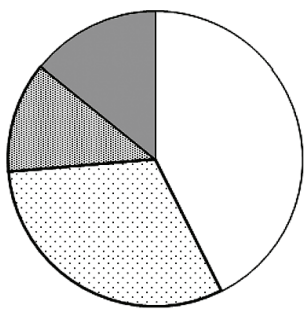

$\square$ Rare QUncommon 国Common $\square$ Verycommon

Figure 5 : Abundance Status of Avifauna in Phewa 


\section{Conservation Status of Recorded Bird Fauna}

Of the recorded species, seven were globally threatened, viz. common pochard (Aythya ferina) Asian wollyneck stork (Ciconia episcopus), Egyptian vulture (Neophron percnopterus), steppe eagle (Aquila nipalensis), white-rumped vulture (Gyps bengalensis), slender-billed vulture (Gyps tenuirostris) and yellow breasted bunting (Emberiza aureola), and 12 were nationally threatened, viz. ferruginous duck (Aythya nyroca), black stork (Ciconia nigra), Egyptian vulture (Neophron percnopterus), Himalayan vulture (Gyps himalayensis), short-eared owl (Asio flammeus), steppe eagle (Aquila nipalensis), great bittern (Botaurus sterallis), northern pintail (Anas acuta), cinereous vulture (Aegypius monachus), whiterumped vulture (Gyps bengalensis), slender-billed vulture (Gyps tenuirostris) and yellow breasted bunting (Gyps bengalensis). In addition, black stork (Ciconia nigra), the protected species by NPWC Act (1973) of Nepal, listed in Schedule I was also recorded.

\section{Species Diversity}

The overall Shannon Wiener Diversity Index $\left(\mathrm{H}^{\prime}\right)$, Margalef's Richness Index $(\mathrm{R})$ and Pielou's Evenness Index (e) were 3.83, 18.64 and 0.77, respectively. Terrestrial birds had the highest Shannon Wiener Diversity Index $\left(\mathrm{H}^{\prime}=3.27\right)$, Margalef's Richness Index $(\mathrm{R}=11.98)$ and Pielou's Evenness Index $(\mathrm{e}=0.74)$ compared to wetland birds (Table 1). This means that terrestrial birds have higher species richness, and are also, evenly distributed than water birds. Similar results have been recorded by Rajpar and Zakaria (2010) at Paya Indah Wetland Reserve, Malaysia and Zakaria, Rajpur (2013) in Man-made marsh, Malaysia. Such dominancy of terrestrial birds over wetland birds seems normal as terrestrial birds being generalists can use all available habitats within the wetland. In addition, the lake is providing diverse habitat such as swamp, dry land, open water body, patches of shrubs and forest edge and abundant food resources, such as insects, grains and safe roosting and breeding sites.

\section{Table 1 : Comparison of Bird Diversity Indices between Terrestrial Birds and Wetland Birds}

\begin{tabular}{|l|c|c|c|}
\hline Indices & Terrestrial bird & Wetland bird & Overall \\
\hline Diversity Indices: Shannon's Index $\left(\mathrm{H}^{\prime}\right)$ & 3.27 & 3.077 & 3.83 \\
\hline Richness Indices: Margalef's Index $(\mathrm{S})$ & 11.98 & 8.44 & 18.64 \\
\hline Evenness Indices: Pielou's Index (e) & 0.74 & 0.73 & 0.77 \\
\hline
\end{tabular}

\section{Relative Abundance}

The maximum relative abundance was recorded for common pigeon $(7.50 \%)$ followed by lesser whistling duck (6.98\%). Common pigeon was abundant among terrestrial birds, and they were found in wetland areas and human 
settlements exhibiting foraging, loafing and breeding activities. Besides, lesser whistling duck was the most abundant among the recorded water birds. It is because ducks prefer deep open water bodies rich in submerged vegetation for foraging and loafing (Rajpar and Zakaria 2011), and similar habitat condition is prevalent in sedimentation part of Phewa wetland. Comparison of relative abundance of abundant terrestrial birds and wetland birds is presented in Table 2.

\section{Table 2 : Comparison of Relative Abundance of Top Five Abundant Terrestrial Birds and Wetland Birds}

\begin{tabular}{|l|l|l|l|l|l|l|}
\hline \multirow{2}{*}{ SN } & \multicolumn{3}{|c|}{ Wetland Bird } & \multicolumn{2}{c|}{ Terrestrial Bird } & \multicolumn{2}{c|}{ Overall } \\
\cline { 2 - 7 } & Species & RA & Species & RA & Species & RA \\
\hline 1 & Lesser- whistling duck & 12.03 & Common pigeon & 17.86 & Common pigeon & 7.50 \\
\hline 2 & Great cormorant & 11.82 & Black kite & 13.57 & Lesser-whistling duck & 6.98 \\
\hline 3 & Common teal & 10.76 & House crow & 9.19 & Great cormorant & 6.86 \\
\hline 4 & Purple swamp hen & 10.71 & Barn swallow & 6.83 & Common teal & 6.24 \\
\hline 5 & Cattle egret & 7.53 & House sparrow & 5.03 & Purple swamp hen & 6.21 \\
\hline
\end{tabular}

\section{Threats to Bird Fauna and their Habitat}

Pollution due to domestic sewages and waste water disposal, habitat destruction due to road construction, disturbances to the birds due to recreational activities including boating, fishing, and paragliding as well as anthropogenic activities, namely, cattle grazing, removal of vegetation, logging, and colonization of lake by water hyacinth were the threats directly observed during the field visits. These threats were also highlighted by Gautam, Kafle (2007) in Phewa wetland, and similar threats are present in other lakes of lake-cluster of Pokhara valley (MOFE 2018). Majority of respondents reported water pollution as the major threats for avifauna and their habitat (Table 3).

Table 3 : Rating of Threats to Bird Fauna and their Habitat

\begin{tabular}{|c|c|c|c|c|c|c|}
\hline \multirow{3}{*}{ Threats } & \multicolumn{5}{|c|}{ Rate / \% Respondents } & \multirow{3}{*}{$\begin{array}{l}\text { Weighted } \\
\text { mean }\end{array}$} \\
\hline & \multicolumn{5}{|c|}{$1 \longleftrightarrow \longrightarrow 5$} & \\
\hline & Very high & High & Medium & Low & Very low & \\
\hline Water pollution & 24.8 & 22 & 20.8 & 23.2 & 9.2 & 2.7 \\
\hline Infrastructural development & 21.2 & 24 & 20 & 15.6 & 19.2 & 2.87 \\
\hline Invasive species & 16 & 20.8 & 29.6 & 20 & 13.6 & 2.94 \\
\hline Habitat destructive activities & 18.4 & 23.2 & 16 & 19.2 & 23.2 & 2.99 \\
\hline Recreational activities & 8 & 18.4 & 20.4 & 35.2 & 18 & 3.37 \\
\hline
\end{tabular}




\section{Conclusion}

This study recorded 2651 bird individuals of 148 species belonging to 104 Genera, 44 Families and 11 Orders. The dominant family was Anatidae and dominant order was Passeriformes. Resident birds emerged as the most predominant with 78 species followed by the winter migrant with 70 species. Of 148 species, seven species were globally threatened and 12 species nationally threatened. Common pigeon was the most abundant bird followed by lesserwhistling duck. As per the abundance status, 63 species were rare, 46 species uncommon, 18 species common and 21 species very common. People reported pollution as a major threat followed by infrastructural development, colonization of invasive species, anthropogenic activities and recreational activities. It is concluded that the area has good potential for bird watching tourism that can integrate economic gain with biodiversity conservation. In this regard, concerned authority need to educate wetland land owners on importance and ecological role of birds in the wetland habitat. Species specific conservation plans and policies of highly threatened species should be prepared and implemented by the local government. In addition, regular monitoring of bird species should be done in and around the wetland areas to assess their status in the corresponding habitat.

\section{Acknowledgment}

We would like to express our deep gratitude to bird experts, Mr. Mann Shant Ghimire and Mrs. Hira Malla for their valuable guidance during the bird survey. We are indebted to Mr. Amrit Poudel, Ms. Anisha Rana, Ms. Rakhshya Thakuri and Ms. Sunita Kunwar for their assistance during field works. Also, we are thankful to all respondents for their kind cooperation during the field work. 


\section{Literature Cited}

Acharya, P.M., Rajbhandari, S.L. (2012): Investigation of Population Status and Habitats of Lutrogale perspicillata in Narayani River, Chitwan National Park. A second phase research report submitted to The Rufford Small Grants Foundation, UK.

Armstrong, D., Richard, Y., Ewen, J., Dimond, W. (2008): Avoiding hasty conclusions about effects of habitat fragmentation. Avian Conservation and Ecology, 3(1).

Baral, H.S. (2009): Updated status of Nepal's wetland birds. Banko Janakari, 30-35.

Baral, H.S., Inskipp, C. (2005): Important Bird Areas in Nepal: Key Sites for Conservation. Bird Conservation Nepal, Kathmandu.

Baral, H.S., Regmi, U.R., Poudyal, L.P., Acharya, R. (2012): Status and Conservation of Birds in Nepal. Biodiversity Conservation in Nepal: A Success Story. Department of National Parks and Wildlife Conservation, Kathmandu, 71-100.

BirdLife International, Crosby, M.J. (2003): Saving Asia's Threatened Birds: a Guide for Government and Civil Society. BirdLife International, Cambridge, UK.

Dixit, A., Karki, M., Shukla, A. (2015): Vulnerability and Impacts Assessment for Adaptation Planning in Panchase Mountain Ecological Region, Nepal. Government of Nepal, United Nations Environment Programme, UNDP, IUCN, German Federal Ministry for the Environment. Nature Conservation, Building and Nuclear Safety and Institute for Social and Environmental Transition-Nepal, Kathmandu, Nepal.

DNPWC, BCN. (2018): Birds of Nepal: An Official Checklist. Department of National Parks and Wildlife Conservation, Kathmandu, Nepal.

Epaphras, A.M., Gereta, E., Lejora, I.A., Mtahiko, M.G. (2007): The importance of shading by riparian vegetation and wetlands in fish survival in stagnant water holes, Great Ruaha River, Tanzania. Wetlands Ecology and Management, 15(4): 329-333.

Gautam, R., Kafle, G. (2007): A preliminary survey of water birds in Phewa lake, Kaski. Environmental Conservation, 28(4): 345-356.

Giri, B., Chalise, M.K. (2008): Seasonal diversity and population status of water birds in Phewa lake, Pokhara, Nepal. Journal of Wetlands Ecology, 3-7. 
Green, A.J., Elmberg, J. (2014): Ecosystem services provided by water birds. Biological Reviews, 89(1): 105-122.

Gregory, R.D., Gibbons, D.W., Donald, P.F., Sutherland, W.J., Newton, I., Green, R.E. (2004): Bird ecology and conservation; a handbook of techniques. Ecology and Conservation, 17-56.

Grimmett, R., Inskipp, C., Inskipp, T., Baral, H.S. (2003): Birds of Nepal. Nepali edition. Helm Field Guide.

Heyojoo, B.P., Takhachhe, P. (2014): An assessment of lake area shrinkage through geospatial approach: case study of Phewa lake of Kaski district, Nepal. International Journal of Multidisciplinary and Current Research, 2: 725-728.

Inskipp, C., Baral, H.S., Phuyal, S., Bhatt, T.R., Khatiwada, M., Inskipp, T., Poudyal, L. (2016): The Status of Nepal's Birds: The National Red List Series. Zoological Society of London, UK.

IUCN Nepal. (2004): A Review of the Status and Threats to Wetlands in Nepal. IUCN Nepal, Kathmandu.

IUCN. (2018): The IUCN Red List of Threatened Species. Version 2017-3 (www.iucnredlist.org)

Khan, M.M.H. (2005): Species diversity, relative abundance and habitat use of the birds in the Sundarban East Wildlife Sanctuary, Bangladesh. FORKTAIL, 21: 79-86.

Margalef, R. (1958): Temporal succession and spatial heterogeneity in phytoplankton. Perspectives in Marine Biology, 323-349.

MoFE. (2018): Integrated Lake Basin Management Plan of Lake Cluster of Pokhara Valley, Nepal (2018-2023). Ministry of Forests and Environment, Kathmandu, Nepal.

Mutagwaba, S.J. (2010): Diversity and Distribution of Avifauna Resource: A Case of Lake Burigi Wetland, North Western Tanzania. Doctoral dissertation, Sokoine University of Agriculture (SUA), Morogoro, Tanzania.

Parchizadeh, J., Williams, S.T. (2018): Water birds targeted in Iran's wetlands. Science. 359(6378): 877-878.

Pielou, E.C. (1966): The measurement of diversity in different types of biological collections. Journal of Theoretical Biology, 13: 131-144. 
Rajpar, M.N., Zakaria, M. (2010): Indah Wetland Reserve, Selangor Peninsular Malaysia. Journal of Biological Sciences, 10(7): 658-666.

Rajpar, M.N., Zakaria, M. (2011): Bird species abundance and their correlationship with microclimate and habitat variables at Natural Wetland Reserve, Peninsular Malaysia. International Journal of Zoology, 2011,

Ralph, C.J., Droege, S., Sauer, J.R. (1995): Managing and monitoring birds using point counts: standards and applications. In: Ralph, C. John, Sauer, John R. and Droege, Sam, Technical editors. Monitoring Bird Populations by Point Counts. Gen. Tech. Rep. PSW-GTR-149. US Department of Agriculture, Forest Service, Pacific Southwest Research Station, Albany, CA. 161-168, 149 pp.

Shannon, C.E., Weiner, W. (1949): The Mathematical Theory of Communication. University of Illinois Press, Urbana. 117 pp.

Tamrakar, R. (2008): Status and Biodiversity of Lakes and Ponds of Lekhnath Municipality. Project paper, Bachelor's degree, Institute of Forestry, Pokhara, Nepal.

Zakaria, M., Rajpar, M. (2013): Density and diversity of water birds and terrestrial birds in man-made Marsh, Malaysia (Ketumpatan dan Kepelbagaian Burung Air dan Burung Daratan di Rawa Buatan Manusia, Malaysia). Sains Malaysiana, 42(10): 1483-1492. 


\section{ANNEX 1}

\section{List of Birds Found in the Study Area}

\begin{tabular}{|c|c|c|c|c|c|c|c|c|c|}
\hline S.N & Species & Scientific name & Family & Order & BT & MS & NCS & IS & RA \\
\hline 1 & $\begin{array}{l}\text { Lesser whistling- } \\
\text { duck }\end{array}$ & $\begin{array}{l}\text { Dendrocygna } \\
\text { javanica }\end{array}$ & Anatidae & Anseriformes & WB & $\mathrm{R}$ & LC & LC & 7 \\
\hline 2 & $\begin{array}{l}\text { Greater white- } \\
\text { fonted goose }\end{array}$ & Anser albifrons & Anatidae & Anseriformes & WB & $\mathrm{V}$ & $\mathrm{V}$ & $\mathrm{LC}$ & 0.15 \\
\hline 3 & Ruddy shelduck & Tadorna ferruginea & Anatidae & Anseriformes & WB & W & NT & $\mathrm{LC}$ & 1.34 \\
\hline 4 & Gadwall & Anas strepera & Anatidae & Anseriformes & WB & W & LC & LC & 0.7 \\
\hline 5 & Eurasian pigeon & Anas penelope & Anatidae & Anseriformes & WB & W & $\mathrm{LC}$ & $\mathrm{LC}$ & 0.23 \\
\hline 6 & Mallard & Anas platyrhynchos & Anatidae & Anseriformes & WB & W & $\mathrm{LC}$ & LC & 4.07 \\
\hline 7 & Northern shoveler & Anas clypeata & Anatidae & Anseriformes & WB & W & $\mathrm{LC}$ & $\mathrm{LC}$ & 0.06 \\
\hline 8 & Northern pintail & Anas acuta & Anatidae & Anseriformes & WB & W & EN & $\mathrm{LC}$ & 0.18 \\
\hline 9 & Common teal & Anas crecca & Anatidae & Anseriformes & WB & W & $\mathrm{LC}$ & LC & 6.28 \\
\hline 10 & $\begin{array}{l}\text { Red-crested } \\
\text { pochard }\end{array}$ & Netta rufina & Anatidae & Anseriformes & WB & W & $\mathrm{LC}$ & LC & 0.03 \\
\hline 11 & Common pochard & Aythya ferina & Anatidae & Anseriformes & WB & W & NT & VU & 0.15 \\
\hline 12 & Ferruginous duck & Aythya nyroca & Anatidae & Anseriformes & WB & W & VU & NT & 0.09 \\
\hline 13 & Tufted duck & Aythya fuligula & Anatidae & Anseriformes & WB & $\mathrm{W}$ & $\mathrm{LC}$ & $\mathrm{LC}$ & 1.43 \\
\hline 14 & Goosander & Mergus merganser & Anatidae & Anseriformes & WB & W & $\mathrm{LC}$ & LC & 0.04 \\
\hline 15 & Greater scaup & Aythya marila & Anatidae & Anseriformes & WB & V & V & LC & 0.22 \\
\hline 16 & Bean goose & Anser fabalis & Anatidae & Anseriformes & WB & $\mathrm{V}$ & $\mathrm{V}$ & $\mathrm{LC}$ & 0.03 \\
\hline 17 & Bar-headed goose & Anser indicus & Anatidae & Anseriformes & WB & $\mathrm{V}$ & NT & $\mathrm{LC}$ & 0.34 \\
\hline 18 & Little grebe & $\begin{array}{l}\text { Tachybaptus } \\
\text { ruficollis }\end{array}$ & Podicipedidae & Anseriformes & WB & W & $\mathrm{LC}$ & LC & 0.37 \\
\hline 19 & Great crested grebe & Podiceps cristatus & Podicipedidae & Anseriformes & WB & W & $\mathrm{LC}$ & LC & 0.14 \\
\hline 20 & Black-necked grebe & Podiceps nigricollis & Podicipedidae & Anseriformes & WB & W & $\mathrm{LC}$ & $\mathrm{LC}$ & 0.04 \\
\hline 21 & $\begin{array}{l}\text { Asian wollyneck } \\
\text { stork }\end{array}$ & Ciconia episcopus & Ciconiidae & Ciconiiformes & WB & W & NT & VU & 0.31 \\
\hline 22 & Black stork & Ciconia nigra & Ciconiidae & Ciconiiformes & WB & W & VU & LC & 0.34 \\
\hline 23 & $\begin{array}{l}\text { Black-crowned night } \\
\text { heron }\end{array}$ & $\begin{array}{l}\text { Nycticorax } \\
\text { nycticorax }\end{array}$ & Ardeidae & Ciconiiformes & WB & $\mathrm{R}$ & $\mathrm{LC}$ & $\mathrm{LC}$ & 1.37 \\
\hline 24 & Indian pond heron & Ardeola grayii & Ardeidae & Ciconiiformes & WB & $\mathrm{R}$ & $\mathrm{LC}$ & $\mathrm{LC}$ & 0.71 \\
\hline 25 & Grey heron & Ardea cinerea & Ardeidae & Ciconiiformes & WB & W & $\mathrm{LC}$ & $\mathrm{LC}$ & 0.5 \\
\hline 26 & Cattle egret & Bubulcus ibis & Ardeidae & Ciconiiformes & WB & $\mathrm{R}$ & $\mathrm{LC}$ & $\mathrm{LC}$ & 4.4 \\
\hline 27 & Great egret & Casmerodius albus & Ardeidae & Ciconiiformes & WB & W & $\mathrm{LC}$ & $\mathrm{LC}$ & 0.18 \\
\hline 28 & Intermediate egret & $\begin{array}{l}\text { Mesophoyx } \\
\text { intermedia }\end{array}$ & Ardeidae & Ciconiiformes & WB & $\mathrm{R}$ & $\mathrm{LC}$ & $\mathrm{LC}$ & 2.07 \\
\hline 29 & Little egret & Egretta garzetta & Ardeidae & Ciconiiformes & WB & $\mathrm{R}$ & $\mathrm{LC}$ & LC & 3.2 \\
\hline
\end{tabular}




\begin{tabular}{|c|c|c|c|c|c|c|c|c|c|}
\hline 30 & Great bittern & Botaurus sterallis & Ardeidae & Ciconiiformes & WB & $\mathrm{P}$ & EN & LC & 0.04 \\
\hline 31 & Great cormorant & $\begin{array}{l}\text { Phalacrocorax } \\
\text { carbo }\end{array}$ & Phalacrocoracidae & Ciconiiformes & WB & W & NT & $\mathrm{LC}$ & 6.9 \\
\hline 32 & Little cormorant & $\begin{array}{l}\text { Phalacrocorax } \\
\text { niger }\end{array}$ & Phalacrocoracidae & Ciconiiformes & WB & W & NT & $\mathrm{LC}$ & 0.29 \\
\hline 33 & Common kestrel & Falco tinnunculus & Falconidae & Falconiformes & TB & $\mathrm{R}$ & LC & $\mathrm{LC}$ & 0.06 \\
\hline 34 & Black kite & Milvus migrans & Accipitridae & Falconiformes & TB & $\mathrm{R}$ & LC & LC & 5.7 \\
\hline 35 & Osprey & Pandion haliaetus & Accipitridae & Falconiformes & TB & W & LC & $\mathrm{LC}$ & 0.28 \\
\hline 36 & Egyptian vulture & $\begin{array}{l}\text { Neophron } \\
\text { percnopterus }\end{array}$ & Accipitridae & Falconiformes & TB & $\mathrm{R}$ & VU & $\mathrm{EN}$ & 0.25 \\
\hline 37 & $\begin{array}{l}\text { White-rumped } \\
\text { vulture }\end{array}$ & Gyps bengalensis & Accipitridae & Falconiformes & TB & $\mathrm{R}$ & $\mathrm{CR}$ & CR & 0.12 \\
\hline 38 & $\begin{array}{l}\text { Slender-billed } \\
\text { vulture }\end{array}$ & Gyps tenuirostris & Accipitridae & Falconiformes & TB & $\mathrm{R}$ & $\mathrm{CR}$ & CR & 0.04 \\
\hline 39 & Himalayan vulture & Gyps himalayensis & Accipitridae & Falconiformes & TB & W & VU & NT & 0.3 \\
\hline 40 & Griffon vulture & Gyps fulvus & Accipitridae & Falconiformes & TB & $\mathrm{P}$ & DD & $\mathrm{LC}$ & 0.03 \\
\hline 41 & Cinereous vulture & Aegypius monachus & Accipitridae & Falconiformes & TB & W & EN & NT & 0.05 \\
\hline 42 & Himalayan buzzard & Buteo buteo & Accipitridae & Falconiformes & TB & W & DD & $\mathrm{LC}$ & 0.04 \\
\hline 53 & Steppe eagle & Aquila nipalensis & Accipitridae & Falconiformes & TB & W & VU & EN & 0.09 \\
\hline 44 & Shikra & Accipiter badius & Accipitridae & Falconiformes & TB & $\mathrm{P}$ & $\mathrm{LC}$ & $\mathrm{LC}$ & 0.07 \\
\hline 45 & Booted eagle & Hieraaetus pennatus & Accipitridae & Falconiformes & TB & $\mathrm{P}$ & LC & $\mathrm{LC}$ & 0.04 \\
\hline 46 & $\begin{array}{l}\text { White-breasted } \\
\text { waterhen }\end{array}$ & $\begin{array}{l}\text { Amauromis } \\
\text { phoenicurus }\end{array}$ & Rallidae & iformes & TB & $\mathrm{R}$ & $\mathrm{LC}$ & $\mathrm{LC}$ & 0.35 \\
\hline 47 & Purple swamp hen & $\begin{array}{l}\text { Porphyrio } \\
\text { porphyrio }\end{array}$ & Rallidae & Falconiformes & WB & $\mathrm{R}$ & LC & LC & 6.23 \\
\hline 48 & Common moorhen & Gallicrex chloropus & Rallidae & Falconiformes & WB & $\mathrm{R}$ & $\mathrm{LC}$ & $\mathrm{LC}$ & 0.41 \\
\hline 49 & Eurasian coot & Fulica atra & Rallidae & Falconiformes & WB & $\mathrm{R}$ & LC & LC & 1.55 \\
\hline 50 & Common crane & Grus grus & Gruidae & Falconiforr & WB & W & NT & $\mathrm{LC}$ & 0.04 \\
\hline 51 & Jack snipe & $\begin{array}{l}\text { Lymnocryptes } \\
\text { minimus }\end{array}$ & Scolopacidae & Falconiformes & WB & W & $\mathrm{LC}$ & $\mathrm{LC}$ & 0.14 \\
\hline 52 & Pin-tailed s & Gallinago stenura & Scolopacidae & Falconiformes & WB & W & LC & LC & 0.09 \\
\hline 53 & Common snipe & Gallinago gallinago & Scolopacidae & Falconiformes & WB & W & LC & LC & 0.21 \\
\hline 54 & Green sandpiper & Tringa ochropus & Scolopacidae & Falconiformes & WB & W & LC & $\mathrm{LC}$ & 0.08 \\
\hline 55 & Common sandpiper & Actitis hypoleucos & Scolopacidae & Falconiformes & WB & W & LC & $\mathrm{LC}$ & 0.08 \\
\hline 56 & Common greenshank & Tringa nebularia & Scolopacidae & Falconiformes & WB & W & $\mathrm{LC}$ & $\mathrm{LC}$ & 0.04 \\
\hline 57 & $\begin{array}{l}\text { Bronzed-winged } \\
\text { jacana }\end{array}$ & Metopidius indicus & Jacanidae & Charadriiformes & WB & $\mathrm{R}$ & LC & LC & 0.32 \\
\hline 58 & River lapwing & Vanellus duvaucelii & Charadeiidae & Charadriiformes & WB & W & NT & NT & 0.04 \\
\hline 59 & Grey-headed lapwing & Vanellus cinereus & Charadeiidae & Charadriiformes & WB & W & LC & $\mathrm{LC}$ & 0.2 \\
\hline 60 & Red-wattled lapwing & Vanellus indicus & Charadeiidae & Charadriiformes & WB & $\mathrm{R}$ & LC & $\mathrm{LC}$ & 0.3 \\
\hline 61 & Little-ringed plover & Charadrius dubius & Charadeiidae & Charadriiformes & WB & W & LC & $\mathrm{LC}$ & 0.14 \\
\hline
\end{tabular}




\begin{tabular}{|c|c|c|c|c|c|c|c|c|c|}
\hline 62 & Greater painted-snipe & $\begin{array}{l}\text { Rostratula } \\
\text { benghalensis }\end{array}$ & Rostratulidae & Charadriiformes & WB & $\mathrm{R}$ & LC & LC & 0.04 \\
\hline 63 & Pallas's gull & $\begin{array}{l}\text { Ichthyaetus } \\
\text { ichthyaetus }\end{array}$ & Laridae & Charadriiformes & WB & $\mathrm{P}$ & LC & NA & 0.04 \\
\hline 64 & Steppe gull & Larus barabensis & Laridae & Charadriiformes & WB & $\mathrm{P}$ & LC & NA & 0.04 \\
\hline 65 & Whiskered tern & Chlidonias hybridus & Laridae & Charadriiformes & WB & $\mathrm{P}$ & $\mathrm{LC}$ & $\mathrm{LC}$ & 0.07 \\
\hline 66 & Common pigeon & Columba livia & Columbidae & Columbiformes & WB & $\mathrm{R}$ & LC & LC & 7.56 \\
\hline 67 & Oriental turtle dove & $\begin{array}{l}\text { Streptopelia } \\
\text { orientalis }\end{array}$ & Columbidae & Columbiformes & TB & W & $\mathrm{LC}$ & $\mathrm{LC}$ & 0.21 \\
\hline 68 & Spotted dove & $\begin{array}{l}\text { Stigmatopelia } \\
\text { chinensis }\end{array}$ & Columbidae & Columbiformes & TB & $\mathrm{R}$ & LC & NA & 0.21 \\
\hline 69 & Rose-ringed parakeet & Psittacula krameri & Psittacidae & Psittaciformes & TB & $\mathrm{R}$ & LC & LC & 0.63 \\
\hline 70 & $\begin{array}{l}\text { Slaty-headed } \\
\text { parakeet }\end{array}$ & $\begin{array}{l}\text { Pssitacula } \\
\text { himalayana }\end{array}$ & Psittacidae & Psittaciformes & TB & $\mathrm{W}$ & LC & LC & 0.27 \\
\hline 71 & Alexandrine parakeet & Psittacula eupatria & Psittacidae & Psittaciformes & TB & $\mathrm{R}$ & NT & NT & 0.04 \\
\hline 72 & Asian Koel & $\begin{array}{l}\text { Eudynas } \\
\text { scolopaceus }\end{array}$ & Cuculidae & Cuculiformes & TB & $\mathrm{R}$ & $\mathrm{LC}$ & NA & 0.02 \\
\hline 73 & $\begin{array}{l}\text { Green-billed } \\
\text { malkoha }\end{array}$ & $\begin{array}{l}\text { Phaenicophaeus } \\
\text { tritis }\end{array}$ & Cuculidae & Cuculiformes & TB & $\mathrm{R}$ & LC & $\mathrm{LC}$ & 0.09 \\
\hline 74 & $\begin{array}{l}\text { Common hawk } \\
\text { cuckoo }\end{array}$ & Hierococcyx varius & Cuculidae & Cuculiformes & TB & $\mathrm{R}$ & LC & LC & 0.04 \\
\hline 75 & Greater coucal & Centropus sinensis & Centropodidae & Cuculiformes & TB & $\mathrm{R}$ & $\mathrm{LC}$ & $\mathrm{LC}$ & 0.09 \\
\hline 76 & Short-eared owl & Asio flammeus & Strigidae & Cuculiformes & TB & $\mathrm{P}$ & $\mathrm{VU}$ & $\mathrm{LC}$ & 0.04 \\
\hline 77 & Spotted owlet & Athene brama & Strigidae & Cuculiformes & TB & $\mathrm{R}$ & $\mathrm{LC}$ & $\mathrm{LC}$ & 0.18 \\
\hline 78 & Asian barred owlet & $\begin{array}{l}\text { Glaucidium } \\
\text { cuculoides }\end{array}$ & Strigidae & Strigiformes & TB & $\mathrm{R}$ & LC & LC & 0.05 \\
\hline 79 & Himalayan swiftlet & $\begin{array}{l}\text { Collocalia } \\
\text { brevirostris }\end{array}$ & Apodidae & Apodiformes & TB & $\mathrm{R}$ & LC & LC & 0.05 \\
\hline 80 & Alpine swift & Tachymarptis melba & Apodidae & Apodiformes & TB & $\mathrm{R}$ & $\mathrm{LC}$ & $\mathrm{LC}$ & 0.15 \\
\hline 81 & House swift & Apus affinis & Apodidae & Apodiformes & TB & $\mathrm{R}$ & $\mathrm{LC}$ & $\mathrm{LC}$ & 0.33 \\
\hline 82 & $\begin{array}{l}\text { White-throated } \\
\text { kingfisher }\end{array}$ & Halcyon smyrnensis & Alcedinidae & Apodiformes & WB & $\mathrm{R}$ & LC & LC & 0.55 \\
\hline 83 & Common kingfisher & Alcedo atthis & Alcedinidae & Apodiformes & WB & $\mathrm{R}$ & LC & LC & 0.08 \\
\hline 84 & Blue-throated barbet & Megalaima asiatica & Megalaimidae & Piciformes & TB & $\mathrm{R}$ & LC & LC & 0.28 \\
\hline 85 & Great barbet & Megalaima virens & Megalaimidae & Piciformes & TB & $\mathrm{R}$ & $\mathrm{LC}$ & $\mathrm{LC}$ & 0.28 \\
\hline 86 & Coppersmith barbet & $\begin{array}{l}\text { Megalaima } \\
\text { haemacephala }\end{array}$ & Megalaimidae & Piciformes & TB & $\mathrm{R}$ & LC & LC & 0.19 \\
\hline 87 & $\begin{array}{l}\text { Fulvous-breasted } \\
\text { woodpecker }\end{array}$ & Dendrocopos macei & Picidae & Piciformes & TB & $\mathrm{R}$ & LC & LC & 0.03 \\
\hline 88 & Lesser yellownape & Picus chlorolophus & Picidae & Piciformes & TB & $\mathrm{R}$ & LC & LC & 0.04 \\
\hline 89 & Greater yellownape & Picus flavinucha & Picidae & Piciformes & TB & $\mathrm{R}$ & $\mathrm{LC}$ & $\mathrm{LC}$ & 0.03 \\
\hline 90 & $\begin{array}{l}\text { Grey-headed } \\
\text { woodpecker }\end{array}$ & Picus canus & Picidae & Piciformes & TB & $\mathrm{R}$ & LC & LC & 0.02 \\
\hline 91 & Greater flameback & $\begin{array}{l}\text { Chrysocolaptes } \\
\text { guttacristatus }\end{array}$ & Picidae & Piciformes & TB & $\mathrm{R}$ & $\mathrm{LC}$ & $\mathrm{LC}$ & 0.02 \\
\hline
\end{tabular}




\begin{tabular}{|c|c|c|c|c|c|c|c|c|c|}
\hline 92 & Long-tailed Minivet & $\begin{array}{l}\text { Pericrocotus } \\
\text { ethologus }\end{array}$ & Campephagidae & Passeriformes & TB & $\mathrm{R}$ & LC & LC & 0.06 \\
\hline 93 & Large cuckooshrike & Coracina macei & Campephagidae & Passeriformes & TB & $\mathrm{R}$ & LC & LC & 0.07 \\
\hline 94 & Long-tailed shrike & Lanius schach & Laniidae & Passeriformes & $\mathrm{TB}$ & $\mathrm{R}$ & LC & LC & 0.21 \\
\hline 95 & Grey-backed shrike & Lanius tephronotus & Laniidae & Passeriformes & TB & W & $\mathrm{LC}$ & $\mathrm{LC}$ & 0.02 \\
\hline 96 & Bronzed drongo & Dicrurus aeneus & Dicruridae & Passeriformes & TB & $\mathrm{R}$ & LC & LC & 0.03 \\
\hline 97 & Black drongo & $\begin{array}{l}\text { Dicrurus } \\
\text { macrocercus }\end{array}$ & Dicruridae & Passeriformes & TB & $\mathrm{R}$ & LC & LC & 0.37 \\
\hline 98 & Spangled drongo & $\begin{array}{l}\text { Dicrurus } \\
\text { hottentottus }\end{array}$ & Dicruridae & Passeriformes & TB & $\mathrm{R}$ & LC & LC & 0.31 \\
\hline 99 & $\begin{array}{l}\text { Yellow-bellied } \\
\text { fantail }\end{array}$ & $\begin{array}{l}\text { Rhipidura } \\
\text { hypoxantha }\end{array}$ & Corvidae & Passeriformes & TB & W & LC & LC & 0.04 \\
\hline 100 & Maroon oriole & Oriolus traillii & Oriolidae & Passeriformes & TB & $\mathrm{R}$ & LC & LC & 0.04 \\
\hline 101 & $\begin{array}{l}\text { Red-billed blue } \\
\text { magpie }\end{array}$ & $\begin{array}{l}\text { Urocissa } \\
\text { erythrorhyncha }\end{array}$ & Corvidae & Passeriformes & TB & $\mathrm{R}$ & LC & LC & 0.28 \\
\hline 102 & Grey treepie & $\begin{array}{l}\text { Dendrocitta } \\
\text { formosae }\end{array}$ & Corvidae & Passeriformes & TB & $\mathrm{R}$ & LC & LC & 0.28 \\
\hline 103 & House crow & Corvus splendens & Corvidae & Passeriformes & TB & $\mathrm{R}$ & $\mathrm{LC}$ & LC & 3.88 \\
\hline 104 & Large-billed crow & $\begin{array}{l}\text { Corvus } \\
\text { macrorhynchos }\end{array}$ & Corvidae & Passeriformes & TB & $\mathrm{R}$ & LC & LC & 1.41 \\
\hline 105 & Rufous treepie & $\begin{array}{l}\text { Dendrocitta } \\
\text { vagabunda }\end{array}$ & Corvidae & Passeriformes & TB & $\mathrm{R}$ & LC & LC & 0.11 \\
\hline 106 & Black-lored tit & $\begin{array}{l}\text { Machlolophus } \\
\text { xanthogenys }\end{array}$ & Paridae & Passeriformes & TB & $\mathrm{R}$ & $\mathrm{LC}$ & $\mathrm{LC}$ & 0.12 \\
\hline 107 & Great tit & Parus major & Paridae & Passeriformes & TB & $\mathrm{R}$ & LC & LC & 0.26 \\
\hline 108 & Plain martin & Riparia chinensis & Hirundinidae & Passeriformes & TB & $\mathrm{R}$ & $\mathrm{LC}$ & $\mathrm{LC}$ & 0.79 \\
\hline 109 & Barn swallow & Hirundo rustica & Hirundinidae & Passeriformes & TB & $\mathrm{R}$ & $\mathrm{LC}$ & $\mathrm{LC}$ & 2.89 \\
\hline 110 & Red-rumped swallow & Cecropis daurica & Hirundinidae & Passeriformes & TB & $\mathrm{R}$ & $\mathrm{LC}$ & $\mathrm{LC}$ & 0.24 \\
\hline 111 & Nepal house martin & Delichon nipalense & Hirundinidae & Passeriformes & TB & $\mathrm{R}$ & $\mathrm{LC}$ & LC & 0.46 \\
\hline 112 & Himalyan bulbul & $\begin{array}{l}\text { Pycnonotus } \\
\text { leucogenys }\end{array}$ & Pycnonotidae & Passeriformes & TB & $\mathrm{R}$ & LC & LC & 0.23 \\
\hline 113 & Red-vented Bulbul & $\begin{array}{l}\text { Pycnonotus } \\
\text { cafer }+ \text { C } 24\end{array}$ & Pycnonotidae & Passeriformes & TB & $\mathrm{R}$ & LC & $\mathrm{LC}$ & 1.07 \\
\hline 114 & $\begin{array}{l}\text { Chestnut-headed } \\
\text { tesia }\end{array}$ & $\begin{array}{l}\text { Cettia } \\
\text { castaneocoronata }\end{array}$ & Sylviidae & Passeriformes & TB & W & LC & LC & 0.03 \\
\hline 115 & Common tailorbird & Orthotomus sutorius & Sylviidae & Passeriformes & $\mathrm{TB}$ & $\mathrm{R}$ & $\mathrm{LC}$ & $\mathrm{LC}$ & 0.34 \\
\hline 116 & Dusky warbler & $\begin{array}{l}\text { Phylloscopus } \\
\text { fuscatus }\end{array}$ & Sylviidae & Passeriformes & TB & W & LC & LC & 0.23 \\
\hline 117 & Smoky warbler & $\begin{array}{l}\text { Phylloscopus } \\
\text { fuligiventer }\end{array}$ & Sylviidae & Passeriformes & TB & W & LC & LC & 0.05 \\
\hline 118 & Buff-barred warbler & $\begin{array}{l}\text { Phylloscopus } \\
\text { pulcher }\end{array}$ & Sylviidae & Passeriformes & TB & W & LC & LC & 0.05 \\
\hline 119 & Hume's leaf warbler & Phylloscopus humei & Sylviidae & Passeriformes & TB & W & LC & LC & 0.1 \\
\hline 120 & Greenish warbler & $\begin{array}{l}\text { Phylloscopus } \\
\text { trochiloides }\end{array}$ & Sylviidae & Passeriformes & TB & W & LC & LC & 0.38 \\
\hline 121 & Grey-hooded warbler & $\begin{array}{l}\text { Phylloscopus } \\
\text { xanthoschistos }\end{array}$ & Sylviidae & Passeriformes & TB & $\mathrm{R}$ & LC & LC & 0.08 \\
\hline
\end{tabular}




\begin{tabular}{|c|c|c|c|c|c|c|c|c|c|}
\hline 122 & Blue whistling thrush & $\begin{array}{l}\text { Myophonus } \\
\text { caeruleus }\end{array}$ & Turdidae & Passeriformes & TB & $\mathrm{R}$ & LC & LC & 0.22 \\
\hline 123 & $\begin{array}{l}\text { White-creasted } \\
\text { laughingthrush }\end{array}$ & $\begin{array}{l}\text { Garrulax } \\
\text { leucolophus }\end{array}$ & Timaliidae & Passeriformes & TB & $\mathrm{R}$ & $\mathrm{LC}$ & NA & 1.09 \\
\hline 124 & Jungle myna & Acridotheres fuscus & Sturnidae & Passeriformes & TB & $\mathrm{R}$ & LC & LC & 0.77 \\
\hline 125 & Common myna & Acridotheres tristis & Sturnidae & Passeriformes & TB & $\mathrm{R}$ & LC & LC & 1.64 \\
\hline 126 & $\begin{array}{l}\text { Oriental magpie } \\
\text { robin }\end{array}$ & Copsycus saularis & Muscicapidae & Passeriformes & TB & $\mathrm{R}$ & $\mathrm{LC}$ & LC & 0.37 \\
\hline 127 & $\begin{array}{l}\text { Plumbeous water } \\
\text { redstart }\end{array}$ & $\begin{array}{l}\text { Rhyacornis } \\
\text { fuliginosa }\end{array}$ & Muscicapidae & Passeriformes & TB & $\mathrm{W}$ & LC & LC & 0.2 \\
\hline 128 & Common stonechat & Saxicola torquatus & Muscicapidae & Passeriformes & TB & $\mathrm{R}$ & $\mathrm{LC}$ & $\mathrm{LC}$ & 1.06 \\
\hline 129 & Pied bushchat & Saxicola caprata & Muscicapidae & Passeriformes & TB & $\mathrm{R}$ & LC & $\mathrm{LC}$ & 0.1 \\
\hline 130 & Taiga flycatcher & Ficedula albicilla & Muscicapidae & Passeriformes & TB & $\mathrm{W}$ & LC & LC & 0.15 \\
\hline 131 & $\begin{array}{l}\text { Grey-headed canary } \\
\text { flycatcher }\end{array}$ & $\begin{array}{l}\text { Culicicapa } \\
\text { ceylonensis }\end{array}$ & Muscicapidae & Passeriformes & TB & W & LC & LC & 0.18 \\
\hline 132 & Slaty-blue flycatcher & Ficedula tricolor & Muscicapidae & Passeriformes & TB & W & LC & LC & 0.04 \\
\hline 133 & Bluethroat & Luscinia svecica & Muscicapidae & Passeriformes & TB & $\mathrm{W}$ & $\mathrm{LC}$ & $\mathrm{LC}$ & 0.02 \\
\hline 134 & Oriental white-eye & $\begin{array}{l}\text { Zosterops } \\
\text { palpebrosus }\end{array}$ & Zosteropidae & Passeriformes & TB & $\mathrm{R}$ & LC & LC & 0.58 \\
\hline 135 & Grey wagtail & Motacilla cinerea & Motacillidae & Passeriformes & WB & W & LC & LC & 0.19 \\
\hline 136 & Citrine wagtail & Motacilla citreola & Motacillidae & Passeriformes & WB & $\mathrm{W}$ & $\mathrm{LC}$ & $\mathrm{LC}$ & 0.05 \\
\hline 137 & White wagtail & Motacilla alba & Motacillidae & Passeriformes & WB & W & $\mathrm{LC}$ & $\mathrm{LC}$ & 0.75 \\
\hline 138 & $\begin{array}{l}\text { White-browed } \\
\text { wagtail }\end{array}$ & $\begin{array}{l}\text { Motacilla } \\
\text { maderaspatensis }\end{array}$ & Motacillidae & Passeriformes & WB & $\mathrm{W}$ & LC & LC & 0.53 \\
\hline 139 & Paddyfield pipit & Anthus rufulus & Motacillidae & Passeriformes & WB & $\mathrm{R}$ & LC & LC & 1.26 \\
\hline 140 & Olive-backed pipit & Anthus hodgsoni & Motacillidae & Passeriformes & WB & W & $\mathrm{LC}$ & $\mathrm{LC}$ & 0.35 \\
\hline 141 & Rosy pipit & Anthus roseatus & Motacillidae & Passeriformes & WB & W & $\mathrm{LC}$ & $\mathrm{LC}$ & 0.15 \\
\hline 142 & $\begin{array}{l}\text { Velvet-fronted } \\
\text { nuthatch }\end{array}$ & Sitta frontalis & Sittidae & Passeriformes & TB & $\mathrm{R}$ & LC & LC & 0.02 \\
\hline 143 & Crimson sunbird & Aethopyga sipraja & Nectariniidae & Passeriformes & TB & $\mathrm{R}$ & $\mathrm{LC}$ & $\mathrm{LC}$ & 0.11 \\
\hline 144 & House sparrow & Passer domesticus & Passeridae & Passeriformes & TB & $\mathrm{R}$ & $\mathrm{LC}$ & $\mathrm{LC}$ & 2.14 \\
\hline 145 & $\begin{array}{l}\text { Eurasian tree } \\
\text { sparrow }\end{array}$ & Passer montanus & Passeridae & Passeriformes & TB & $\mathrm{R}$ & LC & LC & 1.17 \\
\hline 146 & $\begin{array}{l}\text { White-rumped } \\
\text { Munia }\end{array}$ & Lonchura striata & Estrildidae & Passeriformes & TB & $\mathrm{R}$ & $\mathrm{LC}$ & LC & 0.06 \\
\hline 147 & $\begin{array}{l}\text { Orange-bellied } \\
\text { leafbird }\end{array}$ & $\begin{array}{l}\text { Chloropsis } \\
\text { hardwickii }\end{array}$ & Irenidae & Passeriformes & TB & $\mathrm{R}$ & LC & LC & 0.04 \\
\hline 148 & $\begin{array}{l}\text { Yellow breasted } \\
\text { bunting }\end{array}$ & Emberiza aureola & Emberizidae & Passeriformes & WB & $\mathrm{W}$ & $\mathrm{CR}$ & CR & 0.48 \\
\hline
\end{tabular}

